\title{
A study to establish the prevalence of urinary tract infection in preterm labour
}

\author{
Rashmi Kruthipati, Radhika Chethan, Anitha Gabbalkaje Shiva*, \\ Sukanya Suresh, Tejeswini Kolige Krishnappa
}

Department of Obstetrics and Gynaecology, Bangalore Medical College and Research Institute, Bangalore, Karnataka, India

Received: 09 June 2021

Accepted: 24 June 2021

\author{
*Correspondence: \\ Dr. Anitha Gabbalkaje Shiva, \\ E-mail: aninaik85@gmail.com
}

Copyright: (C) the author(s), publisher and licensee Medip Academy. This is an open-access article distributed under the terms of the Creative Commons Attribution Non-Commercial License, which permits unrestricted non-commercial use, distribution, and reproduction in any medium, provided the original work is properly cited.

\begin{abstract}
Background: Urinary tract infection (UTI) is one of the many etiological factors of preterm labour. Preterm labour is the onset of labour after 28 weeks and before 37 weeks of gestation. Preterm labour is a significant cause for perinatal morbidity and mortality. Hence early diagnosis and management of etiological factors is necessary. The most common bacterial infection encountered during pregnancy is UTIs. Early detection and management of UTIs may effectively prevent complications of preterm labour including preterm birth. Aims and objectives of the study was to estimate the prevalence of UTIs in preterm labour.

Methods: cross sectional study with a total of 250 patients carried out in the department of obstetrics and gynaecology, Vanivilas hospital, BMCRI for a period of 6 moths-Aug 2019-Feb 2020. Patients in preterm labour i.e., cervical dilatation $\geq 1 \mathrm{~cm}$, cervical effacement $\geq 80 \%$ with true labour pains were included in the study after taken informed consent form the patient. Detailed clinical history including age of patient, level of education, duration of antenatal care, parity, and obstetrical history was taken. Gestational age was calculated by LMP or early ultrasound. General examination, systemic examination and obstetric examination was done. Routine investigations were done along with clean catch midstream urine sample in a sterile container. Two samples were collected: $1^{\text {st }}$ sample for microscopic examination, $2^{\text {nd }}$ sample for culture and sensitivity.

Conclusions: Untreated UTI can be associated with obstetric complications. The most common bacterial infection during pregnancy is UTIs. All women should be screened for UTI at the first antenatal visit. Once diagnosed it should be promptly treated with suitable antibiotic which is sensitive yet safest.
\end{abstract}

Keywords: UTI, Preterm labour, Bacteriuria, Urine culture sensitivity, Urine routine

\section{INTRODUCTION}

The perinatal morbidity and mortality are 2-7 times more than that of term pregnancy. Preterm neonate suffers many complications during and after delivery. Hence early diagnosis and management of etiological factors is necessary. Preterm births are multifactorial in origin. Chorioamniotis, UTI, anatomical defect of uterus, placental abnormalities and defect in conceptus are the important known causes of preterm labour. Hydramnios, multiple pregnancy, malpresentation, serious maternal disease, psychological problems are other etiological factors. The most common bacterial infection encountered during pregnancy is UTIs. Dilatation of urinary collecting system, mechanical obstruction of ureter and bladder by the gravid uterus causing hypotonia, congestion and some degree of vesicoureteric reflux (VUR) are few of the gestational changes in the urinary tract which lead to increased predisposition of UTI in pregnancy. Bacteriuria causes preterm labour by a mechanism involving placental 
and decidual lysosomal breakage with liberation of enzymes capable of increasing local prostaglandin production.

UTI is diagnosed by clinical findings of bacteriuria (bacteria in midstream urine in counts of $>105$ colony forming units (cfu)/mL) along with symptoms reported by the patient. ${ }^{1}$ Cystitis in pregnancy is associated with increased risk of maternal hypertension, anaemia, amnionitis, preterm labour and low birth weight. ${ }^{2}$ In developed countries where routine screening and treatment of bacteriuria in pregnancy is done, only a small percentage of pregnant women progress to pyelonephritis. ${ }^{3}$

In majority of cases (70 to $90 \%$ ), Escherichia coli is the causative organism. ${ }^{4}$ Kebsiella, Proteus mirabilis, Coagulase negative Staphylococci, Pseudomonas and Group B Streptococci are the other organisms isolated from infected urine. Asymptomatic bacteriuria occurs in 2 to $10 \%$ of pregnant women and symptomatic UTIs including cystitis and pyelonephritis may complicate around $4 \%$ of pregnancies. ${ }^{5,6}$ More importantly 25 to $40 \%$ of asymptomatic patients eventually develop symptom if they remain untreated. ${ }^{6}$ Hence early detection and management of UTIs may effectively prevent complications of preterm labour including preterm birth.

\section{Aims and objectives}

Aims and objectives of the study was to estimate the prevalence of UTIs in preterm labour.

\section{METHODS}

Cross sectional study with a total of 250 patients carried out in the department of obstetrics and gynaecology, Vanivilas hospital, BMCRI for a period of 6 moths-Aug 2019-Feb 2020. Patients in preterm labour i.e., cervical dilatation more than $1 \mathrm{~cm}$, cervical effacement more than $80 \%$ with true labour pains were included in the study after taken informed consent form the patient. Detailed clinical history including age of patient, level of education, duration of antenatal care, parity, obstetrical history was taken. Gestational age was calculated LMP or early ultrasound. General examination, systemic examination and obstetric examination was done. Routine Investigations were done along with clean catch midstream urine sample in a sterile container. Two samples were collected: $1^{\text {st }}$ sample for microscopic examination, $2^{\text {nd }}$ sample for culture and sensitivity. Diagnosis of UTI was based on clinical findings of bacteriuria (bacteria in midstream urine) with bacterial colony counts of $>10^{5}$ colony forming units (cfu) $/ \mathrm{mL}$ along with symptoms reported by the patient.

\section{Exclusion criteria}

Cases with uterine anomalies and congenital anomalies of fetus, cases of intrauterine fetal death, cases with chronic systemic diseases like uncontrolled hypertension, diabetes, nephritis and decompensated heart lesions, induced preterm labour and patients who were already on antibiotics were excluded from the study.

\section{RESULTS}

\section{Age distribution}

Majority of our patients were in the age group between 2630 years. Least belonged to the age group between 36-40 years. 92 patients were of the age group 20-25 years. 3135 years group had 49 patients.

Table 1: Age distribution.

\begin{tabular}{|l|l|}
\hline Age (Years) & No. of patients \\
\hline $\mathbf{2 0 - 2 5}$ & 92 \\
\hline $\mathbf{2 6 - 3 0}$ & 102 \\
\hline $\mathbf{3 1 - 3 5}$ & 49 \\
\hline $\mathbf{3 6}-\mathbf{4 0}$ & 7 \\
\hline
\end{tabular}

\section{Parity}

Gravida 2 was the most common parity on out study. Next common group was G3. Lowest was primi and G4.

Table 2: Obstetric score distribution.

\begin{tabular}{|l|l|}
\hline Parity & No. of patients \\
\hline Primi & 26 \\
\hline G2 & 143 \\
\hline G3 & 54 \\
\hline G4 & 27 \\
\hline
\end{tabular}

\section{Educational status}

Literate patients were slightly lower than the Illiterate patients contributing to 108 and 142 respectively.

Table 3: Educational status.

\begin{tabular}{|ll|}
\hline Educational status & No. of patients \\
\hline Literate & 108 \\
\hline Illiterate & 142 \\
\hline
\end{tabular}

\section{Background}

Rural population in our study was contributed by 77 patients and 173 by urban population.

Table 4: Location of patients.

\begin{tabular}{|l|l|}
\hline Background & No. of patients \\
\hline Urban & 173 \\
\hline Rural & 77 \\
\hline
\end{tabular}

\section{Socio economic status}

Most of our study patients belonged to middle class. Lower class were 29 . Very few patients were from the upper class. 


\section{Booked}

The 29 patients were un-booked. Whereas 221 patients were booked.

Table 5: Socioeconomic status.

\begin{tabular}{|ll|}
\hline Socio economic status & No. of patients \\
\hline Upper & 18 \\
\hline Middle & 203 \\
\hline Lower & 29 \\
\hline
\end{tabular}

Table 6: Booking status.

\begin{tabular}{|ll|}
\hline Variables & No. of patients \\
\hline Booked & 221 \\
\hline Un-booked & 29 \\
\hline
\end{tabular}

\section{Period of gestation}

The 27 patients had preterm labour between 28-30 weeks. 30+1-34 weeks.

Table 7: Gestational age.

\begin{tabular}{|ll|}
\hline $\begin{array}{l}\text { Period of gestation } \\
\text { (Weeks) }\end{array}$ & No. of patients \\
\hline $\mathbf{2 8 - 3 0}$ & 27 \\
\hline $\mathbf{3 0}+\mathbf{1 - 3 4}$ & 58 \\
\hline $\mathbf{3 4 + 1 - 3 7}$ & 165 \\
\hline
\end{tabular}

\section{Urine routine examination}

The $29.2 \%$ was contributed by UTI as a cause of preterm labour in our study.

Table 8: Urine analysis.

\begin{tabular}{|ll|}
\hline $\begin{array}{l}\text { Urine routine } \\
\text { examination }\end{array}$ & No. of patients \\
\hline UTI & 73 \\
\hline Within normal limits & 177 \\
\hline
\end{tabular}

\section{Asymptomatic and symptomatic UTI}

Among the 73 patients found to have UTI, 57 patients were asymptomatic. A very few patients (16) had symptoms.

Table 9: symptom distribution.

\begin{tabular}{|ll|}
\hline Variables & No. of patients \\
\hline Asymptomatic & 57 \\
\hline Symptomatic & 16 \\
\hline
\end{tabular}

\section{Presenting symptoms in symptomatic UTI}

Among the 16 patients with symptomatic UTI, most common symptom was burning micturition. The other common symptoms were pain at supra pubic region, pain during micturition, increased frequency of urination with burning micturition. Less common symptoms were f ever with chills and Incomplete voiding of urine.

Table 10: Presenting symptoms.

\begin{tabular}{|l|l|}
\hline Symptoms & No. of patients \\
\hline Burning micturition & 7 \\
\hline Pain at supra pubic region & 2 \\
\hline Pain during micturition & 2 \\
\hline $\begin{array}{l}\text { Increased frequency of } \\
\text { urination with burning } \\
\text { micturition }\end{array}$ & 3 \\
\hline Fever with chills & 1 \\
\hline Incomplete voiding of urine & 1 \\
\hline
\end{tabular}

Table 11: Culture report.

\begin{tabular}{|c|c|}
\hline Commonest organism & No. of patients \\
\hline E. coli & 29 \\
\hline S. Aureus & 10 \\
\hline Coagulase negative staph & 13 \\
\hline Klebsiella & 17 \\
\hline GBS & 4 \\
\hline
\end{tabular}

\section{Urine culture report}

Commonest organism grown was $E$. coli least was GBS. S. Aureus, coagulase negative staph, Klebsiella were the other organism grown

\section{DISCUSSION}

Preterm labour is a leading cause of neonatal morbidity and mortality worldwide. WHO has estimated that $9.6 \%$ of all births (about 13 million) in 2005 were pre-term. Africa and Asia accounted for almost 11 million. $^{7}$ Evidence suggests that infection plays a role in pathogenesis of preterm labour and delivery. ${ }^{8}$ Lockwood reported that an estimated $50 \%$ of spontaneous preterm births were associated with UTI. ${ }^{9}$ In our study $29.2 \%$ of patients had preterm labour with UTI. In 2001, Chhabra and Patil reported that $28 \%$ of patients in preterm labour had positive urine culture which was found in our study too $(29 \%) .{ }^{10}$ It has been proven by in vivo and in vitro studies that UTIs leads to preterm labour. ${ }^{11-13}$ Hence conducting this study was importance to know the prevalence of UTI causing preterm labour in our population.

In our study majority of patients were in the age group of 26-30 years, gravida 2 was the most common parity similar to that of Pandey et al study. ${ }^{14}$ Literacy rate had no statistical value. Majority of our patients were from urban background similar to McPheeters et al study. ${ }^{15} 88.4 \%$ of our patients were booked. 34+1-37 weeks had the highest percentage of preterm labour with UTI-66\% similar to that of Davidson et al study. ${ }^{5}$ Commonest microorganism isolated in urine culture was E-coli similar to Chhabra and 
Patil. ${ }^{10}$ In the case study, overall UTI was detected in $29.2 \%$ which was 2.67 times more than the other women delivering at term. Our observations are similar to the results of Pandey et al. ${ }^{14}$

In pregnancy, asymptomatic UTI is very common, and is linked with preterm delivery.in our study, asymptomatic UTI was $78 \%$. Among the symptoms burning micturition was the commonest symptom $43 \%$. If bacteriuria without symptoms is not treated in pregnant women, then it may lead to acute cystitis and pyelonephritis in $20-40 \%$ of cases. In 1989, Romero et al concluded in their study that non-bacteriuric patients had only about two-third the risk of low birth weight and half the risk of preterm delivery compared to those with untreated symptomatic bacteriuria, and that antibiotic treatment reduced the risk of low birth weight. ${ }^{16}$ Recognizing and treating the patients having genitourinary infections at a point, when it has not become clinically noticeable, will reduce the number of patients going into preterm labour resulting in decreased morbidity and mortality in the neonates born to such mothers.

\section{CONCLUSION}

Diagnosing and treating infections associated with preterm labour represent a very attractive area for interventions to prevent dire neonatal outcome. This prospective casecontrol study was designed to see the association between preterm labour and UTIs.

\section{Funding: No funding sources}

Conflict of interest: None declared

Ethical approval: The study was approved by the Institutional Ethics Committee

\section{REFERENCES}

1. Gilbert NM, O'brien VP, Hultgren S, Macones G, Lewis WG, Lewis Al. Urinary Tract Infection as a Preventable Cause of Pregnancy Complications: Opportunities, Challenges, and a Global Call to Action Glob Adv Health Med. 2013;2(5):59-69.

2. Schnarr J, Smaill F. Asymptomatic bacteriuria and symptomatic urinary tract infections in pregnancy. Eur J Clin Investig. 2008;38(2):50-7.

3. Gratacos E, Torres PJ. Vila J, Alonso PL, Cararach V. Screening and Treatment of Asymptomatic
Bacteriuria in Pregnancy Prevent Pyelonephritis. J Infect Dis. 1994;169(6):1390-2.

4. Sharma P. Acute pyelonephritis in pregnancy: A retrospective study. Aust N Z J Obstet Gynaecol. 2007;47(4):313-5.

5. Davidson J, Baylis C. Medical Disorders in obstetric Practice $3^{\text {rd }}$ edition, Blackwell Scientific Oxford. 1995;2549.

6. Lucas MJ, Cunningham FG. Urinary Infection in Pregnancy. Clin Obstet Gynecol. 1993;36(4):855-68.

7. Beck S, Wojdyla D, Say L. The worldwide incidence of preterm birth: a systematic review of maternal mortality and morbidity. Bull World Health Organ. 2010;88:31.

8. Romero R, Gomez R, Chaiworapongsa T. The role of infection in preterm labour and delivery. Paediatr Perinat Epidemiol. 2001;15(2):41-56.

9. Lockwood CJ. Predicting premature delivery-no easy task. N Eng J Med. 2002;346:282-4.

10. Chhabra S, Patil N. Study of factors causing and arresting preterm labour. J Obstet Gynecol India. 2001;51:99-103.

11. Keelan JA, Blumenstein M, Helliwell RJA. Cytokines, prostaglandins and parturition-a review. Placenta. 2003;17:S33-46.

12. Romero R, Espinoza J, Chaiworapongsa T. Infection and prematurity and the role of preventive strategies. Semin Neonatol. 2002;7:259-74.

13. Goldenberg RL, Hauth JC, Andrew WW. Intrauterine infection and preterm delivery. N Eng J Med. 2000;342:1500-7.

14. Pandey K, Bhagoliwal A, Gupta N, Katiyar G. Predictive value of various risk factors for preterm labour. J Obstet Gynecol India. 2010;60:141-5.

15. McPheeters ML, Miller WC, Hartmann KE. The epidemiology of threatened preterm labor: a prospective cohort case. Am J Obstet Gynecol. 2005;192(4):1325-9.

16. Romero R, Oyarzun E, Mazor M. Meta-analysis of the relationship between asymptomatic bacteriuria and preterm delivery/low birth weight. Obstet Gynecol. 1989;73:576-642.

Cite this article as: Kruthipati $\mathrm{R}$, Chethan $\mathrm{R}$, Shiva AG, Suresh S, Krishnappa TK. A study to establish the prevalence of urinary tract infection in preterm labour. Int J Reprod Contracept Obstet Gynecol 2021;10:2764-7. 